\title{
PERAN PRAMUWISATA DALAM PROMOSI KEPARIWISATAAN DI BALI
}

\author{
Sang Nyoman Bagus Satya Wira \\ Universitas Udayana \\ Email: bagussatyawira@rocketmail.com \\ Ida Bagus Gde Pujaastawa \\ Universitas Udayana \\ Email: ibg_pujaastawa@yahoo.co.id \\ I Gusti Ayu Oka Suryawardani \\ Universitas Udayana \\ Email: gungdani@gmail.com
}

\begin{abstract}
Tourism promotion is becoming the most important factor for the success of any destination. Every destination is applying the strategy based on its resources. For Balinese tourism, which is enriched by its cultural aspects, the role of tourist guide is still necessarily required. The essence of tourist guiding somehow is rarely recognised as promotional tool that should have been very possible to be focused on. Therefore, this study is aimed to discover the role of tourist guide as indirect promoter for the Balinese tourism. In order to accomplish that objective, examination was laid on Balinese promotion system, expectation of stakeholders/users, and tourist's perception toward the roles of tourist guide. Based on the findings, the author has proposed a concept regarding the utilization of tourist guiding as wordof-mouth promotion strategy for the importance of Balinese tourism. Its composition consists of tourist guide as the promoter; actual tourist as the channel; and potential tourist as the target.
\end{abstract}

Keywords: tourist guide, informal role, tourism promotion, word-of-mouth

\section{Pendahuluan}

Saat ini promosi pariwisata menjadi program prioritas pemerintah, mengingat devisa yang dihasilkan dari industri pariwisata menempati posisi kedua setelah kelapa sawit. Sejalan dengan arahan Presiden, promosi pariwisata nasional menjadi 
agenda kerja pemerintah, khususnya bagi Kementerian Pariwisata. Bali sebagai poros pariwisata Indonesia dijadikan sebagai contoh bagi pengembangan destinasidestinasi wisata baru lainnya. Walaupun telah menginjak usia seratus tahun (Anom dkk., 2017), promosi pariwisata Bali terus menerus dilakukan justru dengan kebijakan dan tat kelola yang semakin disempurnakan. Hal tersebut diketahui dengan diamanatkannya pembentukan Badan Promosi Pariwisata oleh peraturan perundang-undangan (UU No. 10/2009 tentang Kepariwisataan, Bab X, Pasal 48).

Hadirnya BPPD Bali Desember 2013 adalah titik perubahan struktural pada bidang promosi pariwisata. Promosi yang sebelumnya hanya menjadi bagian dari tugas Dinas Pariwisata Daerah Provinsi Bali, saat ini juga melibatkan BPPD Bali dan lembaga/instansi lainnya secara terpadu (Perda No. 2/2012 tentang Kepariwisataan Budaya Bali, Bab VII, Pasal 18). Dalam transisi perubahan tersebut, salah satu terobosan yang dilakukan BPPD Bali adalah bekerjasama dengan media promosi seperti Bali Go Live yang dijadikan sebagai saluran resmi pemerintah Provinsi Bali untuk mempromosikan kepariwisataan Bali melalui media visual yang ditayangkan di dunia maya (Suparta, 2016).

Di sisi lain, Buku Statistik Profil Wisatawan Mancanegara Tahun 2016 (Kemenpar, 2016) justru memperlihatkan fakta yang berbeda. Dari keseluruhan sebelas jenis informasi yang tersedia, ternyata jumlah persentase tertinggi $(55,20 \%)$ dari wisatawan mancanegara menyatakan mereka mengetahui tentang Indonesia dari teman atau saudara. Dengan demikian terdapat kesenjangan antara strategi promosi yang dijalankan BPPD Bali dengan hasil survei yang telah dilakukan Kementrian Pariwisata. Tingginya jumlah wisatawan yang mendapat informasi dari teman/saudara menimbulkan asumsi bahwa promosi dari mulut ke mulut masih lebih efektif dibandingkan dengan jenis promosi melalui media lainnya.

Jauh sebelum terbentuknya BPPD Bali, kegiatan promosi secara konvensional telah dilakukan pemerintah dengan bekerjasama dan melibatkan berbagai pihak seperti penulis buku, kelompok kesenian, jurnalis, seniman, pengusaha industri 
pariwisata, bahkan hingga wisatawan yang notabene ialah konsumen dari produk pariwisata Bali. Adapun keterlibatan wisatawan dalam hal promosi selaras dengan pernyataan dari Geriya (1995) bahwa wisatawan dapat dimanfaatkan sebagai saluran promosi dari mulut ke mulut; sebagaimana umumnya wisatawan akan menceritakan pengalaman dari perjalanan wisata mereka di suatu daerah tujuan wisata kepada keluarga, teman, atau saudara ketika kembali ke negara asal.

Menurut Reisinger (2010) pengalaman adalah produk utama yang mempengaruhi motif wisatawan untuk berkunjung ke suatu destinasi; sedangkan kualitas dari wisatawan sangat tergantung dari pemberian jasa. Dalam konteks pariwisata budaya yang diselenggarakan di Bali, pelayanan jasa dapat diwakilkan secara konkrit oleh kegiatan kepemanduan wisatawan yang melibatkan dua aktor utama yakni pramuwisata dan wisatawan. Menurut World Federation of Tourist Guide Association (WFTGA) pramuwisata ialah seseorang yang memandu wisatawan sesuai bahasa pilihan mereka dan menginterpretasikan warisan alam dan budaya dari suatu daerah; di mana orang tersebut mempunyai kualifikasi khusus yang umumnya diterbitkan dan/atau dikenali oleh otoritas setempat (WFTGA, 2003). Selanjutnya, definisi standar wisatawan ialah pengunjung di suatu negara yang dikunjunginya, setidak-tidaknya tinggal 24 jam dan datang berdasakan motivasi yang antara lain: (1).mengisi waktu senggang (bersenang-senang, berlibur, untuk kesehatan, studi, keperluan agama, dan olahraga); dan/atau (2).bisnis, keluarga, perutusan, dan pertemuan-pertemuan (UN Statistical Commision, 1968).

Secara akademis, kajian kepemanduan wisatawan telah menjadi sorotan sejak lebih dari tiga dasawarsa. Studi khusus tentang peranan pramuwisata dipelopori oleh J. Christopher Holloway melalui sebuah kajian yang menggunakan teori peran. Awalnya, ia menemukan bahwa peran utama pramuwisata adalah sebagai pemberi informasi; tetapi kemudian banyak penulis melakukan penelitian lanjutan dan menemukan peran-peran pramuwisata lainnya sesuai dengan perspektif dan latar belakang penelitian mereka (Holloway, 1981). 
Salah satu karya penting lainnya tentang peran pramuwisata digagas oleh Betty Weiler yang menyebutkan bahwa pramuwisata tidak hanya memiliki peranan semata-mata untuk kepentingan wisatawan, akan tetapi juga memiliki peranan ke dalam untuk kepentingan tuan rumah dan segala sumber daya pariwisatanya. Ia menyatakan bahwa pramuwisata dapat berperan sebagai agen atau motivator dari nilai konservasi dalam konteks pemeliharaan sumber daya pariwisata suatu destinasi (Weiler, 1991).

Studi lanjutan oleh Rosemary Black dan Betty Weiler tentang kepemanduan wisatawan telah berhasil mendaftarkan beberapa peran pramuwisata yang dirangkum dari beberapa penulis. Peran-peran pramuwisata tersebut antara lain: penerjemah, pemberi informasi, pemimpin, motivator dari nilai konservasi, katalisator, penunjuk arah, mediator, organiser, representatif, dan fasilitator (Black dan Weiler, 2005). Ditemukannya peran-peran tersebut di atas, telah memberikan suatu nilai penting yang dapat berguna bagi kemajuan industri pariwisata suatu destinasi, maupun secara khusus profesi pramuwisata itu sendiri.

Dari uraian di atas, dapat diketahui bahwa peran pramuwisata secara umum memiliki rentang yang cukup luas dan meliputi berbagai aspek kepariwisataan. Walaupun demikian, peran pramuwisata di Bali sampai saat ini belum teridentifikasi dengan jelas. Beberapa studi tentang pramuwisata Bali yang berhasil ditemukan antara lain berdasarkan perspektif kompetensi pramuwisata (Purnomo dkk., 2016), pengaruh jasa pramuwisata terhadap kepuasan wisatawan (Yudi dkk., 2015), eksistensi pramuwisata ilegal (Yanis, 2012) dan pelaksanaan aturan hukum Perda Provinsi Bali tentang Pramuwisata (Fajar, 2015). Sedangkan sangat disayangkan bahwa studi tentang peran pramuwisata bagi pariwisata Bali belum pernah ditelusuri oleh para penulis sebelumnya.

Berdasarkan uraian di atas, maka pada tulisan ini peran pramuwisata ditelusuri dengan cara memeriksa serangkaian ekspektasi dari stakeholders; dari pihak-pihak yang menaunginya; dari pihak-pihak yang memiliki kepentingan dengannya; 
maupun dari wisatawan yang secara langsung menggunakan jasanya. Secara bersamaan, praktik kegiatan kepemanduan wisatawan di lapangan juga diteliti secara parsial pada situasi-situasi yang diasumsikan sebagai kegiatan mempromosikan segala sesuatu yang berkaitan dengan kepariwisataan Bali. Terlepas dari kegiatan promosi telah secara administratif menjadi tugas Pemerintah Daerah, BPPD Bali, dan lembaga/instansi lainnya; tulisan ini secara khusus bertujuan untuk mengungkap bagaimana peran pramuwisata dalam kerangka promosi pariwisata yang terintegrasi.

\section{Landasan Teori dan Konsep}

\section{Teori peran informal}

Dalam teori peran perspektif Turner (2001) terdapat kajian tentang peran keorganisasian. Menurut Turner (2001:243) peran informal berpijak dari asumsi bahwa selalu ada ketidaksesuaian antara konsepsi dan prilaku peran. Ketidaksesuaian tersebut sangat lazim terjadi pada bidang peran keorganisasian karena beberapa faktor khusus seperti formalisasi, jarak antara penentu peran (role definers) dan petahana/pelaku peran (role incumbents), serta kekakuan dalam keorganisasian terhadap percobaan perubahan adaptatif. Sebagai hasilnya pelaku peran mengembangkan suatu peran informal, sebagaimana peran tersebut jauh berbeda dari peran formalnya.

Teori peran informal Turner (2001) dirasa dapat menunjang penelitian ini. Peran pramuwisata Bali sangat menarik untuk diteliti oleh karena terdapat ketidakpastian atas peran formal yang diberlakukan kepada mereka. Pramuwisata di Bali memiliki serangkaian peran yang diekspektasikan oleh beberapa stakeholders dan users seperti pemerintah, organisasi, pramuwisata, dan biro perjalanan wisata. Pemerintah memberlakukan Peraturan Daerah (No. 5 Tahun 2016) tentang Pramuwisata; organisasi pramuwisata DPD HPI Bali memberlakukan kode etik pramuwisata; sedangkan biro perjalanan wisata tempatnya bekerja juga memberlakukan deskripsi 
kerja yang berbeda untuk pramuwisata. Adapun keberagaman peran pramuwisata Bali tersebut di atas menjadi pijakan atas studi yang dilakukan.

\section{Teori atribusi}

Teori atribusi adalah suatu teori tentang pembentukan suatu persepsi dalam rangka memahami prilaku individu. Berbeda dengan pembentukan persepsi terhadap benda, atribusi diaplikasikan pada prilaku individu yang lebih kompleks sebagaimana prilaku tersebut biasanya dipengaruhi oleh latar belakang sudut pandang, motif, dan kebiasaan yang subjektif. Pada dasarnya, teori ini menjelaskan bagaimana seseorang membentuk suatu persepsi menurut pemaknaan yang diatribusikan kepada prilaku orang lain (Robbins, 1998:94).

Menurut Robbins (1998:95-96), persepsi dipengaruhi oleh tiga faktor yakni: (1) distinctiveness, (2) consensus, (3) consistency. Dalam tulisan ini faktor yang digunakan untuk memahami persepsi wisatawan terhadap pramuwisata adalah konsensus. Konsensus yang dimaksud adalah ketika suatu kelompok yang dihadapkan pada situasi tertentu kemudian memberikan respon yang relatif sama. Sesuai dengan uraian tersebut, maka dalam tulisan ini wisatawan berlaku sebagai perceiver dan pramuwisata adalah targetnya. Ketika dikaitkan dengan situasi kepemanduan, maka persepsi wisatawan terbentuk berdasarkan penyebab internal dan eksternal. Penyebab internal dinilai dari dimensi profil wisatawan yang dikelompokkan berdasarkan: (1) jenis kelamin, (2) negara asal, dan rentang usia. Penyebab eksternal dinilai dari dimensi kemampuan pramuwisata sebagai penerjemah dan/atau penafsir dan sebagai promotor bagi kepariwisataan Bali.

\section{Metode Penelitian}

Penelitian yang membangun tulisan ini diselesaikan dengan menggunakan metode dan strategi kualitatif dari penelitian karya John W. Creswell (2009). Pendekatan kualitatif dipilih dengan alasan bahwa fenomena promosi pariwisata di Bali yang ingin ditelusuri sangat kompleks dan sulit untuk dipahami hanya dengan 
melihatnya melalui suatu perspektif. Dengan ditentukannya promosi pariwisata sebagai fenomena yang diteliti dan peran pramuwisata sebagai fokus bahasannya, maka ditentukan Bali sebagai lokasi penelitian.

Sebagian besar data dalam penelitian ini berupa data kualitatif dan sebagian kecil lainnya berupa data kuantitatif. Data kualitatif berupa keterangan atau informasi-informasi deskriptif mengenai kualitas makna atau sifat-sifat dari suatu gejala yang diperoleh melaui observasi, wawancara, studi pustaka, dan pemeriksaan dokumen. Sedangkan data kuantitatif berupa keterangan atau informasi yang diwakili oleh angka-angka; di mana itu diperoleh melalui penyebaran kuesioner dan pemeriksaan dokumen atau catatan-catatan statistik.

Instrumen kunci dari penelitian observasi partisipasif adalah peneliti itu sendiri. Kemampuan peneliti untuk menentukan pendekatan, metode, dan teknik penelitian sangat mempengaruhi hasil dari penelitian. Terlepas dari peneliti menjadi instrumen kunci dalam tulisan ini, terdapat juga instrumen-instrumen yang digunakan untuk mengumpulkan data seperti pedoman wawancara, kuesioner, dan instrumen lainnya. Teknik pengumpulan data terdiri dari observasi, wawancara, penyebaran kuesioner, dan dokumentasi.

Analisis data dilakukan berdasarkan teknik analisi data kualitatif yang bersifat menyeluruh. Proses analisis tersebut terstruktur oleh enam tahapan utama, yakni (i) organisasi dan persiapan data, (ii) pemeriksaan data, (iii) kodifikasi, (iv) pendeskripsian, (v) narasi, dan (vi) interpretasi. Analisis berlangsung selama pengumpulan data di lapangan, dan dilakukan secara terus-menerus hingga akhirnya ditarik suatu simpulan. Sebagian besar hasil analisis data disajikan secara informal atau naratif, sedangkan untuk menunjang proses verifikasi maka sebagian kecil dari hasil analisis data yang berupa perolehan angka-angka hasil survei disajikan dalam bentuk tabel. 


\section{Hasil Penelitian}

\section{Sistem promosi pariwisata Bali}

Sistem promosi pariwisata Bali diatur berdasarkan regulasi yang terdiri dari UU No. 10/2009 tentang Kepariwisataan dan Perda No. 2/2012 tentang Kepariwisataan Budaya Bali. Dalam pada itu diuraikan definisi oprasional beserta komponenkomponen dari sistem tersebut sebagaimana dalam tulisan ini disebut sebagai stakeholders. Adapun stakeholders dari sistem promosi pariwisata Bali terdiri dari pemerintah, asosiasi, usaha biro perjalanan wisata (BPW) dan pramuwisata, usaha lainnya, dan masyarakat.

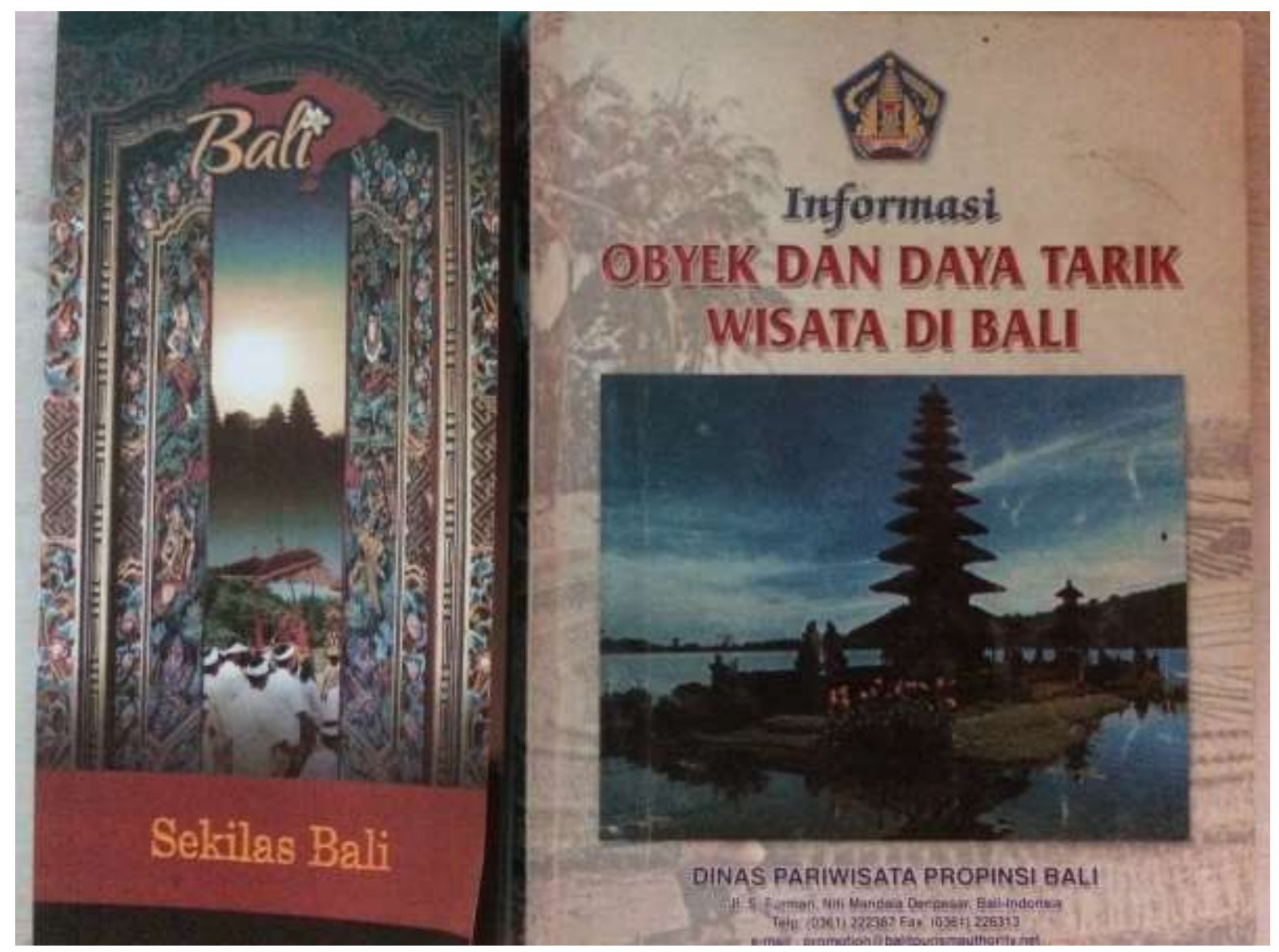

Gambar 1. Contoh Promosi Tidak Langsung melalui Media Cetak oleh Dinas Pariwisata Daerah Provinsi Bali

Sumber : Dokumentasi peneliti (2018) 
Sementara hubungan dan proses interaksi dari masing-masing stakeholders terintegrasi baik secara struktural maupun secara privat antara satu dengan yang lainnya. Sebagai hasil dari hubungan dan proses interaksi tersebut berhasil diungkap mekanisme kerja teraktual dari sistem promosi pariwisata Bali. Adapun mekanisme kerja sistem tersebut terdiri dari beberapa jenis promosi seperti: (a) promosi destinasi dan produk dibedakan berdasarkan tahapan dan konten promosinya; (b) promosi langsung dan tidak langsung dibedakan berdasarkan media promosinya; (c) promosi offline dan online dibedakan berdasarkan penggunaan internet; serta (d) promosi formal dan informal sebagaimana keduanya dibedakan berdasarkan keabsahannya di mata hukum atau regulasi yang berlaku.

\section{Peran pramuwisata dalam promosi kepariwisataan di Bali}

\section{Multi peran pramuwisata}

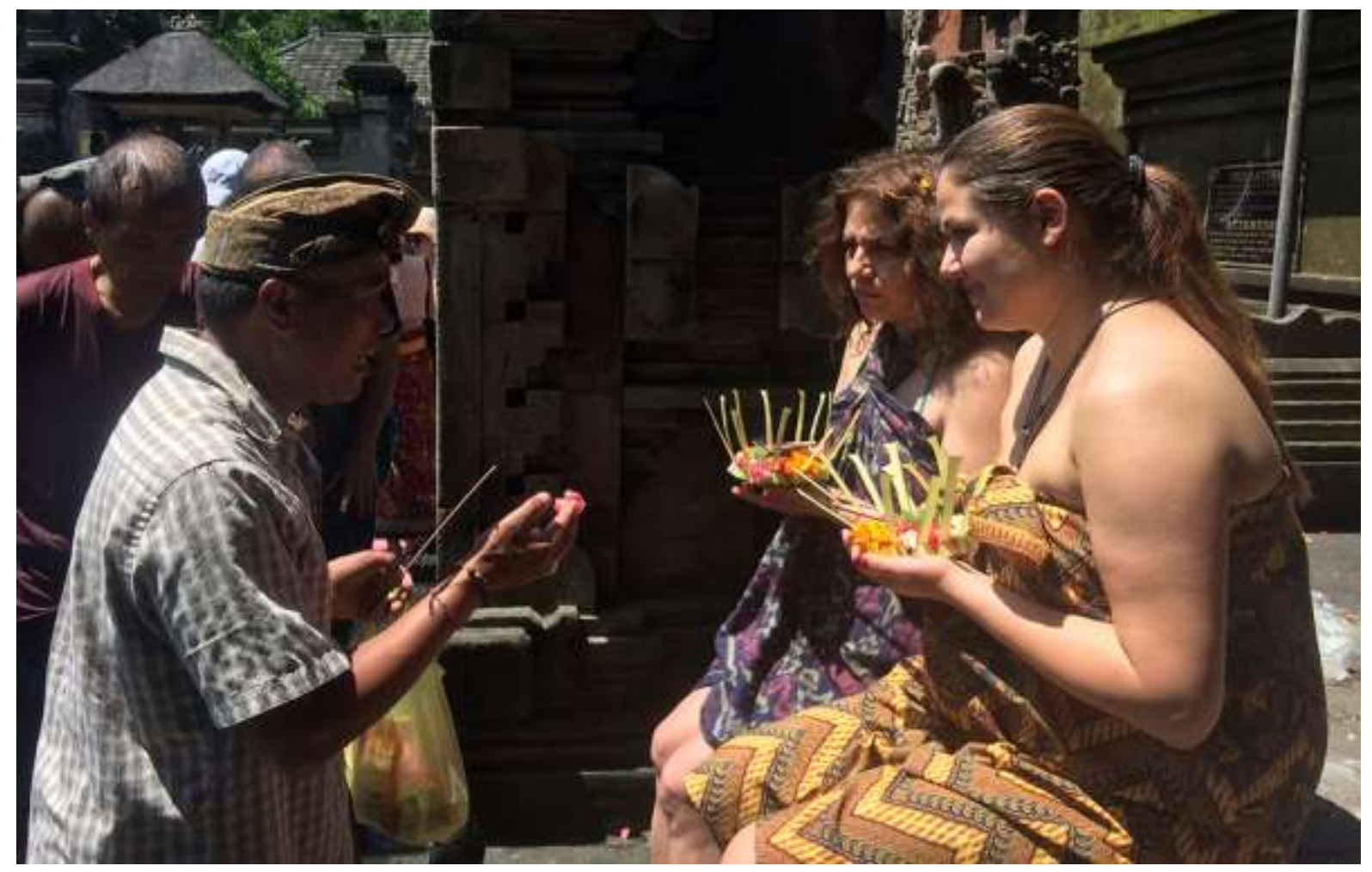

Gambar 2. Interaksi antara Pramuwisata dan Wisatawan di Pura Tirta Empul Sumber : Dokumentasi peneliti (2018) 
Dalam tulisan ini berhasil diungkap beberapa peran pramuwisata setelah dilakukan analisis ekspektasi terhadap regulasi yang mengatur tentang pelaksanaan jasa pramuwisata, pemangku kepentingan, dan pengguna jasa. Sebagai hasilnya, ditemukan sembilan peran pramuwisata di Bali yang antara lain sebagai: (a) pemberi informasi, (b) pemberi kesan, (c) pencipta suasana, (d) penerjemah, (e) pemberi edukasi, (f) pemberi pelayanan, (g) pelindung budaya, (h) representatif, dan (i) promotor.

\section{Pengelompokan peran pramuwisata}

Sebagaimana diketahui dalam tulisan ini bahwa konsep ekspektasi peran dari teori peran Turner (2001) dapat digunakan untuk mengidentifikasi keberadaan suatu peran. Peran-peran pramuwisata yang berhasil diungkap berdasarkan analisis ekspektasi yang diberlakukan (enacted expectation), dikelompokkan ke dalam peran di bidang kepemanduan; sedangkan peran-peran pramuwisata yang berhasil diungkap berdasarkan analisis ekspektasi yang dirasakan (perceived expectation), dikelompokkan ke dalam peran di bidang promosi. Peran-peran pramuwisata yang termasuk dalam kelompok peran di bidang kepemanduan adalah: (a) pemberi informasi, (b) pemberi kesan, (c) pencipta suasana, (d) penerjemah, (e) pemberi edukasi, (f) pemberi pelayanan, dan (g) pelindung budaya. Peran-peran pramuwisata yang termasuk dalam kelompok peran di bidang promosi adalah: (h) representatif dan (i) promotor.

\section{Promosi dari mulut ke mulut bidang kepemanduan wisatawan}

Bertolak dari temuan pada masing-masing seksi bahasan sebelumnya baik mengenai sistem promosi pariwisata Bali, maupun peran pramuwisata di dalam sistem tersebut; kemudian keduanya dikonvergensikan dengan konsep-konsep yang menunjang tulisan ini. Sebagai hasilnya dapat dideskripsikan bagaimana terjadinya promosi dari mulut ke mulut bidang kepemanduan wisatawan. Adapun promosi yang dimaksud, dapat dipahami dengan memperhatikan gambar sebagai berikut. 


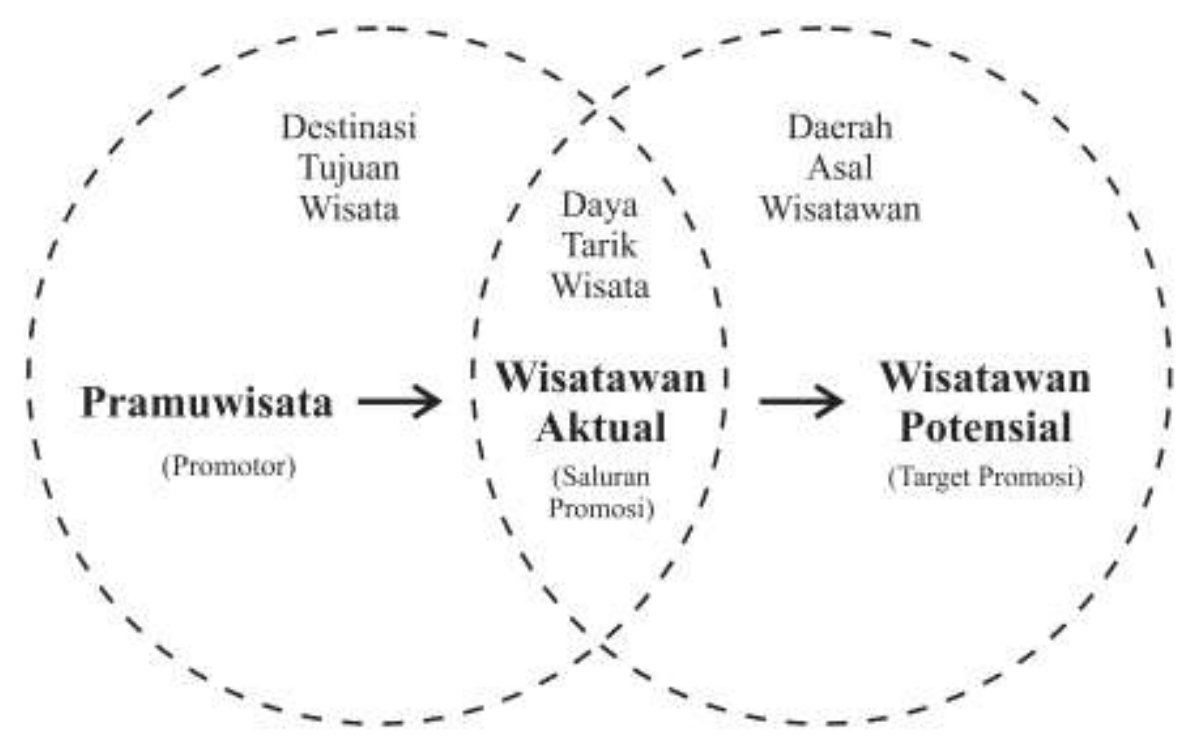

Gambar 3. Skema Promosi dari Mulut ke Mulut Substansi Promosional Kepariwisataan Budaya Bali bidang Kepemanduan Wisatawan Sumber : Adaptasi dari Silverman (2011)

Gambar di atas adalah sebuah skema alur distribusi substansi promosional yang terjadi secara berurutan; dari pramuwisata kepada wisatawan aktual, kemudian dilanjutkan oleh wisatawan aktual kepada wisatawan potensial. Adapun skema tersebut di atas jika secara eklektik dikaitkan dengan konsep enam (6) M word-ofmouth (Silverman, 2011), maka dapat diketahui bahwa komposisi yang dibutuhkan untuk mendistribusikan substansi promosional/messages dalam kerangka promosi dari mulut ke mulut kepariwisataan Bali meliputi: (1) pramuwisata sebagai promotor/mavens, (2) wisatawan aktual sebagai saluran/means, dan (3) wisatawan potensial sebagai targetnya.

Masih berkaitan dengan gambar tersebut di atas, diketahui bahwa dalam suatu perjalanan wisata di Bali yang dipandu oleh pramuwisata, melalui tiga tahap spasial yang sesuai dengan model moments-of-truth (Hyken, 2016) yang terdiri dari (1) destinasi tujuan wisata, (2) daya tarik wisata, dan terakhir pada (3) daerah asal wisatawan. Adapun maksud dari masing-masing tahapan dijelaskan pada uraian selanjutnya. 
Yang dimaksud destinasi tujuan wisata dalam tulisan ini adalah Pulau Bali secara umum. Ketika tiba di Bali, wisatawan mungkin telah memiliki gambaran tentang Bali secara umum yang didapatkan dari sumber informasi mereka masingmasing sebelumnya. Pertemuan mereka dengan pramuwisata di pintu gerbang kedatangan dapat menjadi peralihan dari apa yang mereka bayangkan tentang Bali, kepada kenyataan bahwa mereka telah berada di Bali. Peralihan yang disebutkan di atas adalah suatu peralihan dari zero MoT ke first MoT. Pada tahap ini wisatawan merangkai suatu gambaran tentang Bali dengan bantuan penjelasan dari pramuwisata.

Tahap kedua atau second MoT dari skema promosi pariwisata budaya Bali adalah pada daya tarik wisata (selanjutnya disebut DTW). Ketika berada di Bali wisatawan umumnya melakukan perjanan wisata atau tour ke tempat-tempat yang menjadi DTW. Keberadaan wisatawan di DTW dapat melengkapi gambaran yang mereka secara lebih spesifik pada sebuah konsep pariwisata budaya yang diselenggarakan Bali. Pada tahap ini peran-peran pramuwisata sangat penting untuk menciptakan pengalaman wisatawan secara keseluruhan. Dalam konteks produsen-konsumen, wujud dari produk pariwisata budaya Bali sangat memungkinkan untuk dinilai oleh wisatawan ketika melakukan tour yang dipandu oleh pramuwisata. Dengan demikian, baik atau buruknya pengalaman wisatawan adalah cerminan dari pelayanan yang diberikan oleh pramuwisata.

Setelah habis waktu liburan mereka di Bali, wisatawan kembali ke negara asal mereka. Ini adalah tahap ketiga atau third MoT dari skema promosi pariwisata budaya Bali pada bidang kepemanduan wisatawan. Pada tahap ini wisatawan umumnya menceritakan tentang pengalaman mereka yang terdiri dari keseluruhan kesan dan/atau pengalaman yang mereka rasakan ketika berlibur di Bali. Kendati produk pariwisata Bali sangat beragam wujudnya, tetapi secara khusus dalam konteks pariwisata budaya, pengalaman kebudayaan wisatawan sangat tergantung dari performa pramuwisata. Adapun pengalaman kebudayaan wisatawan yang 
diperoleh dari pramuwisata, nantinya menjadi substansi promosional yang disebarkan secara mulut ke mulut oleh wisatawan itu sendiri. Dengan demikian promosi kepariwisataan budaya Bali baru dapat dikatakan terfasilitasi secara komprehensif.

\section{Persepsi wisatawan terhadap peran pramuwisata Bali}

Kendati telah dideskripsikan mengenai keberadaan peran pramuwisata berdasarkan perspektif internal destinasi, namun kurang lengkap jika tidak dihadirkan bahasan mengenai keberadaan peran tersebut berdasarkan perspektif eksternal. Oleh sebab itu, maka pada bagian ini disajikan hasil penelitian mengenai persepsi wisatawan terhadap peran pramuwisata di Bali. Adapun persepsi wisatawan ditelusuri melalui survei terhadap responden $(\mathrm{N}=122)$ yang dipilih sesuai kriteria, yakni mereka yang menggunakan jasa pramuwisata selama berlibur di Bali. Hasil survei berupa angka disajikan dalam bentuk tabel, sebagaimana diuraikan sebagai berikut.

Persepsi wisatawan terhadap kemampuan pramuwisata dalam menjalankan perannya di bidang kepemanduan

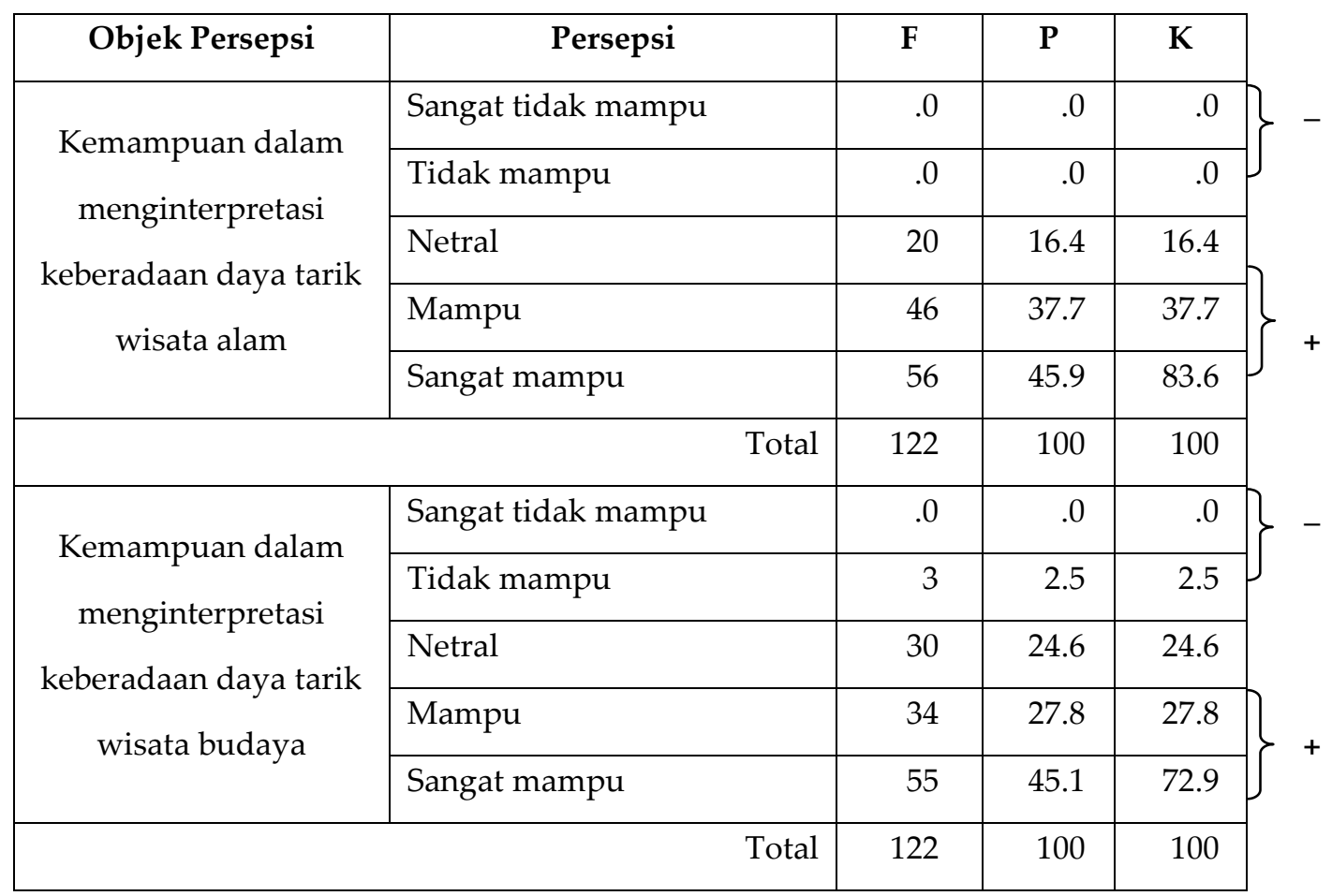

(Sumber: Olahan data hasil penyebaran kuesioner) 
Sang Nyoman Bagus Satya Wira, I. B. Gde Pujaastawa, I Gusti Ayu Oka Suryawardani

\section{Keterangan}

$N$ : jumlah total/keseluruhan responden

$F$ : frekuensi jawaban responden

$P$ :proporsi (dalam persen)

$K$ : nilai kumulatif (dalam persen)

Persepsi wisatawan mengenai peran pramuwisata dalam bidang promosi

\begin{tabular}{|c|c|c|c|c|}
\hline Objek Persepsi & Persepsi & $\mathbf{F}$ & $\mathbf{P}$ & $\mathbf{K}$ \\
\hline Intensitas informasi & $\begin{array}{l}\text { Sama sekali tidak } \\
\text { pernah }\end{array}$ & 6 & 4.92 & 4.92 \\
\hline tarik wisata yang & Sesekali & 12 & 9.84 & 14.76 \\
\hline \multirow{2}{*}{$\begin{array}{l}\text { didapatkan } \\
\text { wisatawan dari }\end{array}$} & Beberapa kali & 27 & 22.13 & 22.13 \\
\hline & Sering & 48 & 39.34 & 61.47 \\
\hline pramuwisata & Sangat sering & 29 & 23.77 & 85.24 \\
\hline \multicolumn{2}{|r|}{ Total } & 122 & 100 & 100 \\
\hline \multirow{4}{*}{$\begin{array}{c}\text { Kemampuan } \\
\text { pramuwisata dalam } \\
\text { berperan sebagai }\end{array}$} & Sangat tidak mampu & 4 & 3.28 & 3.28 \\
\hline & Tidak mampu & 2 & 1.64 & 4.92 \\
\hline & Netral & 23 & 18.86 & 18.86 \\
\hline & Mampu & 57 & 46.72 & 46.72 \\
\hline promotor & Sangat mampu & 36 & 29.50 & 76.22 \\
\hline \multicolumn{2}{|r|}{ Total } & 122 & 100 & 100 \\
\hline
\end{tabular}

(Sumber: Olahan data hasil penyebaran kuesioner)

Keterangan

$N$ : jumlah total/keseluruhan responden

$F$ : frekuensi jawaban responden

$P$ :proporsi (dalam persen)

$K$ : nilai kumulatif (dalam persen) 


\section{Pembahasan}

Studi terdahulu tentang kepemanduan wisatawan di Bali lebih cendrung melihat bahwa esensi dari kegiatan kepemanduan hanya terbatas untuk memuaskan wisatawan semata. Berkaitan dengan itu, sebagian besar studi tentang kepemanduan wisatawan memilih untuk menitikberatkan permasalahan pada pramuwisata; sebagaimana topik yang dipilih antara lain seperti eksistensi pramuwisata ilegal (Yanis, 2012), pelaksanaan aturan hukum Perda Provinsi Bali tentang Pramuwisata (Fajar, 2015), kinerja pramuwisata (Purnomo dkk., 2016), dan kepuasan wisatawan (Yudi dkk., 2015; Putra dkk., 2017).

Berbeda dengan uraian di atas, studi pada lingkup makro justru memilih untuk mengungkap peran internal pramuwisata yang ditujukan untuk kepentingan tuan rumah destinasi/host beserta sumber daya pariwisatanya (Weiler dan Davis, 1992; Weiler dan Black, 2015). Dalam rangka melengkapi kekurangan dari penelitianpenelitian sebelumnya, maka tulisan ini diselesaikan untuk keluar dari tradisi penelitian kepemanduan wisatawan yang telah dilakukan selama ini di Bali.

Sesuai dengan hasil penelitian yang telah diuraikan sebelumnya, maka diketahui bahwa sistem promosi pariwisata Bali merupakan suatu sistem yang holistik dan terintegrasi. Para pemangku kepentingan yang terdiri dari pemerintah, asosiasi, industri, dan masyarakat berinteraksi dan berperan secara terpadu untuk menyukseskan promosi tersebut. Dalam hubungan dan interaksi yang bersifat promosional, pramuwisata memiliki orbit yang paling strategis. Oleh sebab itu, maka diketahui bahwa pramuwisata selain memiliki peran di bidang kepemanduan, ternyata juga memiliki peran di bidang promosi. 


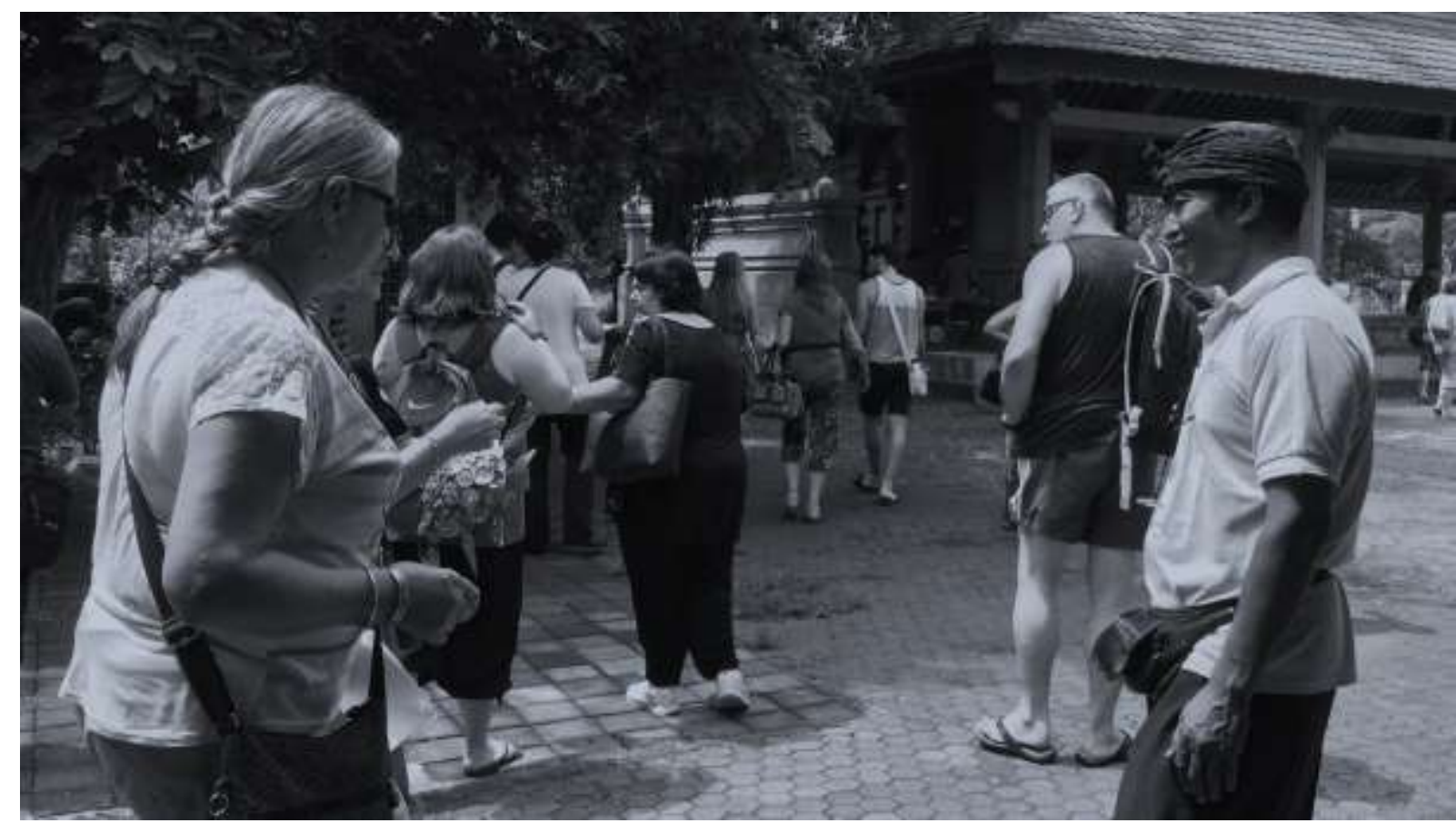

Gambar 4. Pramuwisata Menjemput Wisatawan usai Pertunjukan Seni Tari Barong di Pura Puseh Tegaltamu Batubulan Sumber : Dokumentasi peneliti (2018)

Pada tulisan ini ditemukan suatu pertalian antara peran mendasar pramuwisata sebagai interpreter di bidang kepemanduan dengan peran mereka di bidang promosi. Adapun peran tersebut telah diverifikasi melalui survei terhadap persepsi wisatawan yang menggunakan jasanya. Sebagai hasilnya diketahui bahwa wisatawan memiliki persepsi positif terhadap peran pramuwisata, baik di bidang kepemanduan maupun di bidang promosi. Keberadaan peran pramuwisata sebagai promotor sebagaimana ditunjang oleh persepsi positif wisatawan terhadap peran tersebut menunjukkan suatu potensi bagi pendayagunaan kepemanduan sebagai strategi praktis promosi kepariwisataan budaya Bali.

Kondisi kepariwisataan Bali yang sarat dengan budaya menyebabkan masih tingginya permintaan akan jasa pramuwisata. Kemampuan pramuwisata dalam menyampaikan interpretasi daya tarik wisata dapat membentuk pengalaman kognitif bagi wisatawan aktual. Pengalaman yang diperoleh wisatawan dari pramuwisata tersebut, jarang disadari sebagai substansi promosional yang nantinya 
dapat disalurkan dari wisatawan aktual kepada keluarga, teman, atau kerabat (wisatawan potensial) di daerah asal mereka.

Dari keseluruhan hasil analisis yang secara eklektik dipadukan dengan konsep word-of-mouth (Silverman, 2011) dan moments-of-truth (Hyken, 2016) diajukan suatu konsepsi pendayagunaan kegiatan kepemanduan wisatawan sebagai suatu strategi praktis promosi dari mulut ke mulut kepariwisataan Bali. Dalam pada strategi tersebut, dapat dipahami secara komprehensif bagaimana peran pramuwisata sebagai promotor tersembunyi dalam promosi kepariwisataan di Bali.

\section{Simpulan dan Saran}

Berdasarkan analisis terhadap permasalahan dalam penelitian ini, maka dapat ditarik simpulan sebagai berikut.

Sistem promosi pariwisata Bali adalah suatu sistem yang regulasinya ditetapkan berdasarkan peraturan perundang-undangan, yakni UU Nomor 10 Tahun 2009 tentang Kepariwisataan dan Perda Provinsi Bali Nomor 2 Tahun 2012 tentang Kepariwisataan Budaya Bali. Komponen dari sistem tersebut terdiri dari pemerintah (Disparda Provinsi Bali dan BPPD Provinsi Bali), asosiasi anggota dari GIPI Provinsi Bali (utamanya ASITA), usaha biro perjalanan wisata dan pramuwisata, instansi/usaha lainnya yang bergerak di bidang pariwisata, dan masyarakat. Dari komponen yang disebutkan di atas selanjutnya diketahui terdapat hubungan dan interaksi antara pemerintah dan asosiasi; pemerintah dan masyarakat; asosiasi dan anggotanya; serta antar-usaha industri pariwisata. Mekanisme kerja sistem tersebut terdiri dari promosi destinasi dan produk; promosi langsung dan tidak langsung; promosi online dan offline; serta promosi formal dan informal. Pertalian antara satu komponen dengan yang lainnya secara konvergen bertujuan untuk menyukseskan promosi pada tiap celah yang tersedia. Sebagai keluaran atau output dari sistem promosi tersebut adalah suatu promosi yang bersifat holistik dan terintegrasi. Pada sebagian besar interaksi, diketahui bahwa biro perjalanan wisata dan pramuwisata 
merupakan dua komponen yang paling sering dilibatkan. Intensitas pertemuan antara pramuwisata dan wisatawan yang relatif tinggi menempatkan pramuwisata pada orbit yang paling strategis.

Peran-peran dari pramuwisata Bali diungkap berdasarkan analisis ekspektasi dari pemangku kepentingan dan pengguna jasa. Adapun ekspektasi tersebut terdiri dari ekspektasi yang diberlakukan (enacted expectation) dan ekspektasi yang dirasakan atau dipersepsikan (perceived expectation). Berdasarkan analisis ekspektasi yang diberlakukan, ditemukan tujuh peran pramuwisata yang antara lain adalah sebagai pemberi informasi, pemberi kesan, pencipta suasana, penerjemah, pemberi edukasi, pemberi pelayanan, dan pelindung budaya. Berdasarkan analisis ekspektasi yang dirasakan atau dipersepsikan, ditemukan dua peran pramuwisata yakni sebagai representatif dan promotor. Dari serangkaian peran pramuwisata yang disebutkan di atas, diketahui bahwa pada dasarnya peran pramuwisata secara khusus di Bali adalah sebagai interpreter dari produk kepariwisataan yang disebut sebagai daya tarik wisata. Dalam pada peran tersebut terselip suatu peran yang berkaitan dengan bidang promosi; yakni peran pramuwisata sebagai promotor tersembunyi. Pramuwisata disebut sebagai promotor tersembunyi oleh karena peran pramuwisata tersebut tidak dikenali, baik oleh peraturan perundang-undangan maupun otoritas yang mengatur tentang pelaksanaan jasa pramuwisata.

Keberadaan peran pramuwisata secara khusus di bidang promosi diverifikasi melalui survei yang telah dilakukan terhadap persepsi wisatawan aktual yang mengkonsumsi jasa pramuwisata. Sebagai hasilnya, diketahui bahwa persepsi wisatawan terhadap peran pramuwisata di bidang promosi berada dalam kategori positif. Dengan demikian, walaupun tidak dikenali oleh peraturan perundangundangan yang berlaku di Bali, tetapi peran pramuwisata sebagai promotor dapat dipahami secara komprehensif. 
Berdasarkan uraian pada simpulan di atas, pada bagian ini diajukan keterbatasan beserta saran dari tulisan ini. Adapun keterbatasan dan saran yang diajukan adalah sebagai berikut.

Secara akademis, hasil penelitian ini sebaiknya dapat dijadikan suatu kebaruan bagi tradisi penelitian mengenai kepemanduan wisatawan di Bali yang selama ini berkutat pada pandangan bahwa kepemanduan wisatawan dipahami sebagai alat untuk mewujudkan kepuasan wisatawan semata. Temuan dari penelitian ini mengenai peran pramuwisata dalam promosi kepariwisataan dapat digunakan sebagai pinjakan untuk melakukan kajian yang lebih luas dan mendalam terhadap baik peran pramuwisata, maupun masalah-masalah yang berkaitan dengan promosi kepariwisataan di Bali.

Secara praktis, dianjurkan bagi pihak penyusun dan pelaksana kebijakan, serta pemangku kepentingan di bidang kepariwisataan untuk menerapkan hasil penelitian ini sebagai paduan yang dapat melengkapi strategi promosi kepariwisataan Bali secara menyeluruh. Adapun strategi yang dianjurkan berdasarkan hasil penelitian ini adalah strategi promosi dari mulut ke mulut memanfaatkan kepemanduan wisatawan. Pemahaman mengenai strategi tersebut didasari oleh konsepsi pendayagunaan kepemanduan wisatawan sebagaimana pramuwisata dapat didayagunakan sebagai promotor; wisatawan aktual dapat didayagunakan sebagai saluran promosi; dan wisatawan potensial ditentukan sebagai targetnya. Proses penyaluran substansi promosional kepemanduan wisatawan melalui tiga dimensi spasial yang terdiri dari destinasi, daya tarik wisata, dan negara asal wisatawan. Dari ketiga dimensi tersebut, kunci kesuksesan promosi terletak pada daya tarik wisata. Dengan memastikan wisatawan mengunjungi daya tarik wisata ditemani oleh pramuwisata berkompeten, profesional, dan sadar akan peran mereka sebagai promotor; maka promosi dari mulut ke mulut dapat terjadi secara alami. Keunggulan dari penerapan strategi promosi ini adalah promosi jangka panjang yang berkelanjutan oleh karena promosi dari mulut ke mulut 
memiliki tingkat kepercayaan yang tinggi; sehingga dapat menjadi tepisan bagi persepsi skeptis wisatawan sebagaimana diakibatkan oleh kelebihan beban informasi dari jenis-jenis promosi lainnya yang dirasakan kurang sesuai dengan konsep Kepariwisataan Budaya Bali.

\section{Daftar Pustaka}

Anom, I. P., Suryasih, I. A., Nugroho, S. \& Mahagangga, I. G. A. O., 2017. Turismemorfosis: Tahapan selama Seratus Tahun Perkembangan dan Prediksi Pariwisata Bali. Jurnal Kajian Bali, 7(2), hal. 59-80.

Ardana, I Gusti Gede. 2007. Pemberdayaan Kearifan Lokal Masyarakat Bali dalam Menghadapi Budaya Global. Pustaka Tarukan Agung.

Ashrama, B., Pitana, I. G. \& Windia, W. 2007. Bali is Bali Forever. Sustainable in the Framework of Tri Hita Karana. Denpasar: Bali Travel News.

Black, R. \& Weiler, B. 2005. Quality Assurance and Regulatory Mechanisms in The Tour Guiding Industry: A Systematic Review. Journal of Tourism Studies, 16(1), hal. 24-37.

Blyablina, A. 2015. The Contribution of Guides in Developing Tourist Experiences during Historical Theatrical Tours: The Case of Stockholm Ghost Walk (tesis). Sweden: Mid-Sweden University.

BTB Bali. t.t. What is BTB/GIPI Bali?. Tentang Bali Tourism Board. Tersedia dari URL: http://balitourismboard.or.id/page/about-us/what-is-btb-gipi.html

Carlzon, J., t.t. Moments of Truth: New Strategies for Today's Customer Driven Economy, Book Report by Gary Tomlinson: Tomlinson \& Associates.

Chilembwe, J. M. \& Mweiwa, V. 2014. Tour Guides: Are They Tourism Promoters and Developers? Case Study of Malawi. IMPACT: International Journal of Research in Business Management, 2(9), hal. 29-46.

Cohen, E. 1985. The Tourist Guide: The Origins, Structure and Dynamics of a Role. Annals of Tourism Research, Volume 12, hal. 5-29.

Creswell, J. W. 2009. Research Design: Qualitative, Quantitative, and Mixed Methods Ahalroaches 3rd ed.. California: SAGE Publications Inc.

Dahles, H. 2002. The Politic of Guiding: Image Management in Indonesia. Annals of Tourism Research, 29(3), p. 783-800.

Dahles, H. \& Bras, K. 1999. Tourism and Small Entrepreneurs. Development, National Policy and Entrepreneurial Culture. Indonesian Cases. New York: Cognizant Communication Corporation. 
Entrepreneur Media, Inc. 2017. Small Business Encyclopedia: Word-of-Mouth Advertising. Tersedia dari: https://www.entrepreneur.com/encyclopedia/word-of-mouth-advertising

Fajar, N. M. A. P. 2015. Pelaksanaan Peraturan Daerah Bali No. 5 Tahun 2008 di Kabupaten Badung, Denpasar: Universitas Udayana.

Geriya, W. 1995. Pariwisata dan Dinamika Kebudayaan Lokal, Nasional, Global: Bunga Rampai Antropologi Pariwisata. Denpasar: Upasada Sastra.

Goffman, E. 1959. The Presentation of Self in Everyday Life. Garden City(New York): Doubleday.

Gremler, D. D. Gwinner, K. P. \& Brown, S. W. 2001. Generating Positive Word-ofMouth through Customer-Employee Relationships. International Journal of Service Industry Management, 1(12), hal. 44-69.

Gurung, G. Simmons, D. \& Devlin, P. 1996. The Evolving Role of Tourist Guides: The Nepali Experience. In Tourism and Indigenous Peoples, R. Butler and T. Hinch eds. London: International Thomson Business Press.

Holloway, J. 1981. The Guided Tour: A Sociological Approach. Annals of Tourism Research, 8(3), hal. 377-402.

Hyken, S. 2016. The New Moment of Truth in Business. Forbes, 9 April. Tersedia dari: https://www.forbes.com/sites/shephyken/2016/04/09/new-moment-of-truthin-business/\#2c0930ea38d9

Hu, W. 2007. Tour Guides and Sustainable Development: The Case of Hainan, China (disertasi), Ontario: University of Waterloo.

Larsen, J. \& Meged, J. W. 2013. Tourists Co-producing Guided Tours. Scandinavian Journal of Hospitality and Tourism, 13(2), hal. 88-102.

Lee-Ross, D. 2010. Understanding the Role of the Service Encounter in Tourism, Hospitality, and Leisure Services. In: J. Kandampully, C. Mok \& B. Sparks, eds. Service Quality Management in Hospitality, Tourism, and Leisure. New York: Routledge, hal. 85-96.

Linton, R. 1936. The Study of Man: An Introduction. Student's ed. New York: Ahalleton-Century-Crofts, Inc.

Litvin, S. W., Goldsmith, R. E. \& Pan, B. 2006. Electronic Word-of-Mouth in Hospitality and Tourism Management, South Carolina: Department of Hospitality and Tourism, College of Charleston.

Mead, G. H. 1934. Mind, Self and Society: From the Standpoint of a Social Behaviorist. Chicago: University of Chicago Press.

Merton, R. K. 1957. The Role-Set: Problems in Sociological Theory. The British Journal of Sociology, 8(2), hal. 106-120. 
Moteka, L. 2014. Role Perceptions and Behaviour Change Patterns of Tour Guides (tesis), Stavanger: University of Stavanger.

Peraturan Daerah Provinsi Bali Nomor 2 Tahun 2012 tentang Kepariwisataan Budaya Bali.

Peraturan Daerah Provinsi Bali Nomor 5 Tahun 2016 tentang Pramuwisata.

Pereira, A. M. 2015. Tour Guides and Destination Image: Evidence From Portugal. Journal of Tourism and Hospitality Management, hal. 129-150.

Pereira, E. M. \& Mykletun, R. J. 2012. Guides as Contributors to Sustainable Tourism? A Case Study from the Amazon. Scandinavian Journal of Hospitality and Tourism, 12(1), hal. 74-94.

PHRI Bali. 2013. Berharap dari Badan Promosi Pariwisata Daerah (BPPD). PHRI News. Tersedia dari URL: http://www.phribali.or.id/news/berharap-daribadan-promosi-pariwisata-daerah-bppd.htm

Pond, K. 1993. The Professional Guide: Dynamics of Tour Guiding. New York: Van Nostrand Reinhold.

Pujaastawa, I.B.G. \& Ariana, Nyoman. 2015. Pedoman Identifikasi Potensi Daya Tarik Wisata. Denpasar: Pustaka Larasan.

Purnomo, D. Sudana, I. P. \& Mananda, I. G. S., 2016. Pengaruh Pendidikan dan Pelatihan terhadap Kompetensi serta Dampaknya pada Kinerja Pramuwisata Bali. Jurnal IPTA, 4(2), hal. 52-57.

Purwaningsih, R. M. 2013. Pengaruh Kualitas Pelayanan Pemandu Wisata terhadap Kepuasan Wisatawan di Candi Perambanan. Jurnal Nasional Pariwisata, hal. 146-153.

Putra, I. B. P. S., Negara, I. M. K., Wijaya, N. M. S. 2017. Persepsi Wisatawan Terhadap Kualitas Pelayanan Pramuwisata di Bali. Jurnal IPTA, 5(1), hal. 2934.

Robbins, S. P. 1998. Organizational Behavior. International $\left(8^{\text {th }}\right)$ ed. New Jersey: Prentice-Hall Inc.

Rabotić, B. 2008. Tourist Guides as Cultural Heritage Interpreters: Belgrade Experience with Municipality-sponsored Guided Walks for Local Residents. hal. 213-233.

Reisinger, Y. 2010. Unique Characteristics of Tourism, Hospitality, and Leisure Services. In: J. Kandampully, C. Mok \& B. Sparks, eds. Service Quality Management in Hospitality, Tourism, and Leisure. New York: Routledge, hal. 1549

_.2010. Concepts of Tourism, Hospitality, and Leisure Service. In: J. Kandampully, C. Mok \& B. Sparks, eds. Service Quality Management in Hospitality, Tourism, and Leisure. New York: Routledge, hal. 1-14. 
Reisinger, Y. \& Steiner, C. 2006. Reconceptualising Interpretation: The Role of Tour Guides in Authentic Tourism. Current Issues in Tourism, 9(6), hal. 481-498.

Ritzer, G. \& Goodman, D. J. 2004. Teori Sosiologi Modern. 6th ed. Jakarta: Pranada Media.

Sarpong, S. 2016. The Service Industry and the Moment of Truth: The Quest for the Holy Grail. Athens Journal of Tourism, (3)1, Hal. 25-40.

Schmidt, C. J. 1979. The Guided Tour. Urban Life, 7(4), hal. 441-467.

Sekaran, U. 2003. Research Method for Business. 4th ed. New York: John Wiley \& Sons Inc.

Silverman, G. 2011. The Secrets of Word-of-Mouth Marketing. New York: AMACOM.

Soekadijo, R. G. 1996. Anatomi Pariwisata: Memahami Pariwisata sebagai Systemic Linkage. Jakarta: Gramedia Pustaka Utama.

Subaya, S. P. 2017. Pramuwisata dari Berbagai Perspektif. Majalah Cendrawasih, Vol. 1: hal. 75-76

Sudira, I. M. 2012. Pariwisata adalah Guide. Majalah Cakrawala, Vol. 1: hal. 15-17.

Suparta, I. K. 2016. Promosi Pariwisata Bali Melalui Digital. Antara News, 10 Mei. Tersedia dari: https://bali.antaranews.com/berita/90259/promosi-pariwisatabali-melalui-digital

Turner, R. H. 2001. Role Theory. In: Handbook of Sociological Theory. New York: Springer, hal. 233-254.

Undang-Undang Republik Indonesia Nomor 10 Tahun 2009 tentang Kepariwisataan.

Weiler, B. \& Black, R. 2015. Tour Guiding Research: Insight, Issues, and Implications. Bristol: Channel View Publications.

Weiler, B., Johnson, T. \& Davis, D. 1992. Roles of the Tour Leader in Environmental Responsible Tourism. Canberra, Bureau of Tourism Research, hal. 228-233.

World Federation of Tourist Guide Association. 2003. Tourist Guiding: What is a Tourist Guide?. Tersedia dari: http://www.wftga.org

Yanis, I. N., 2012. Efektivitas Pelaksanaan Peraturan Daerah Bali No 5 tahun 2008 tentang Pramuwisata (tesis). Denpasar: Universitas Udayana

Yasvari, T. H., Ghassemi, R. A. \& Rahrovy, E. 2002. Influential Factors on Word of Mouth in Service Industries (The Case of Iran Airline Company). International Journal of Learning $\mathcal{E}$ Development, 2(5), hal. 227-242.

Yudi, I. K. T., Karini, N. M. O. \& Dewi, L. G. L. K. D. 2015. Pengaruh Kualitas Pelayanan Pramuwisata Lokal Terhadap Kepusasan dan Loyalitas Wisatawan di Daya Tarik Wisata Alas Kedaton Tabanan. Jurnal IPTA, 3(1), hal. 25-31. 
Zhang, H. Q. \& Chow, I., 2004. Ahallication of importance-performance model in tour guides' performance: Evidence from mainland Chinese outbound visitors in Hong Kong. Tourism Management, 25(1), hal. 81-91.

\section{Profil Penulis}

Sang Nyoman Bagus Satya Wira ialah alumnus Program Studi Magister Kajian Pariwisata Universitas Udayana Tahun 2018. Minat studi adalah penelitian kepramuwisataan.

Ida Bagus Gde Pujaastawa ialah pembimbing utama dari penulisan tesis ini. Bidang keahlian yang ditekuninya adalah pariwisata budaya, pariwisata berbasis masyarakat, dan metode kualitatif penelitian pariwisata.

I Gusti Ayu Oka Suryawardani ialah pembimbing kedua dari penulisan tesis ini. Bidang keahlian yang ditekuninya adalah prilaku konsumen, ekonomi pariwisata, dan permodelan sistem pariwisata. 